\title{
Pengklasifikasian Grade Telur Ayam Negeri menggunakan Klasifikasi $K$-Nearest Neighbor berbasis Android
}

\author{
NUR IBRAHIM ${ }^{1}$, TASYA FIKRIYAH BACHERAMSYAH ${ }^{2}$, BAMBANG HIDAYAT ${ }^{3}$, \\ SJAFRIL DARANA ${ }^{4}$ \\ 1,2,3Universitas Telkom \\ ${ }^{4}$ Universitas Padjajaran \\ Email: nuribrahim@telkomuniversity.ac.id
}

Received 23 Januari 2018 | Revised 14 Mei 2018 | Accepted 25 Mei 2018

\begin{abstract}
ABSTRAK
Telur ayam negeri yang dibeli oleh masyarakat Indonesia di toko swalayan, pasar, ataupun di peternakan memiliki grade yang berbeda-beda. Pada penelitian sebelumnya, telah dilakukan pembuatan sistem pengklasifikasian telur ayam dengan berbasis Windows, namun belum dapat digunakan secara praktis oleh masyarakat. Penelitian ini dilakukan agar masyarakat dapat menggunakannya di lapangan dalam mengklasifikasikan grade telur ayam negeri, dimana pengklasifikasian grade pada telur ayam negeri ini menggunakan klasifikasi $K$ Nearest Neighbor (K-NN) yang berbasis android. Berdasarkan hasil pengujian, sistem ini dapat mengklasifikasikan grade telur ayam negeri dengan tingkat akurasi sebesar 80\% (dibandingkan menggunakan Haugh Unit Micrometer) menggunakan parameter layer 4 (grayscale), metode penghitungan jarak cosine, dan nilai $k=1$ dimana jumlah tetangga yang dibandingkan pada algoritma $K-N N$ adalah 1.
\end{abstract}

Kata kunci: K-NN, telur ayam negeri, android.

\begin{abstract}
Chicken eggs purchased by Indonesian people in supermarkets, markets, or farms have different grades. In the previous research, the classification system of chicken eggs has been done in the windows platform, but it cannot be used practically by the people. This research was made so the people can use it on the field to classify chicken eggs grade, using the classification of $K$-Nearest Neighbor ( $K-N N)$ based on android. Based on testing results of this system, can classify eggs grade chicken with an accuracy of $80 \%$ (compared with Haugh Unit Micrometer) using layer 4 (grayscale), cosine distance method, and value of $k=1$ which is the total of compared neighborhood in K-NN algorithm is 1.
\end{abstract}

Keywords: K-NN, chicken egg, android. 


\section{PENDAHULUAN}

Ada beberapa cara untuk mengetahui kualitas telur yang baik, salah satunya dapat dilihat dari ketebalan putih telur atau albumen. Tinggi rendahnya albumen adalah patokan untuk mengetahui kesegaran telur. Tinggi rendahnya albumen dapat diukur oleh alat Haugh Unit. Saat ini warna kuning telur tidak dapat dijadikan patokan utama dalam menentukan kualitas telur ayam, karena perkembangan teknologi memungkinkan kamuflase kuning telur dengan zat kimia atau zat herbal (Tim Praktikum Produksi Ternak Unggas, 2013). Oleh karena itu, ketebalan putih telur dapat menjadi alternatif patokan utama dalam menentukan kualitas telur.

Penelitian sebelumnya merancang deteksi kualitas dan kesegaran telur menggunakan berbagai metode ekstraksi ciri, yaitu Fuzzy Color Histogram (Wardani, 2017), Histogram Equalization (Meirinda, 2016), dan ekstraksi ciri Wavelet (Basuki, 2016) dengan metode klasifikasi yang sama yaitu K-NN. Pada klasifikasi Fuzzy Color Histogram diperoleh tingkat akurasi $71,87 \%$, sedangkan pada metode Histogram Equalization diperoleh akurasi sebesar $76 \%$ dan pada metode ekstraksi ciri Wavelet diperoleh akurasi sebesar $81,81 \%$. Pada penelitian (Handayani, 2017), deteksi kualitas telur ayam menggunakan Discrete Cosine Transform (DCT) memiliki tingkat akurasi yang cukup tinggi yaitu sebesar 90.19\%, dimana penelitiannya menggunakan platform windows dengan software Matlab. Kekurangan dari penggunaan platform windows adalah tidak mudah digunakan di lapangan karena harus mengambil citra gambar telur ayam dengan menggunakan kamera, kemudian memasukkan citra kamera tersebut ke dalam komputer, dan hasilnya baru bisa diketahui setelahnya. Oleh karena itu, peneliti membuat sistem pengklasifikasian grade telur ayam negeri menggunakan klasifikasi $K$-Nearest Neighbor berbasis android agar masyarakat, terutama distributor dan peternak telur ayam negeri dapat lebih mudah melakukan pengukuran kualitas telur di lapangan. Jenis kualitas telur dapat diklasifikasikan menjadi empat kualitas, yaitu : AA (sangat baik), A (Baik), B (Cukup Baik), dan C (Buruk).

\subsection{Citra Digital}

Citra digital merupakan representatif dari citra yang diambil oleh mesin dengan bentuk pendekatan berdasarkan sampling dan kuantisasi. Sampling pada citra menyatakan besar kecilnya ukuran piksel (titik) pada citra, dan kuantisasi menyatakan besarnya nilai tingkat kecerahan yang dinyatakan dalam nilai tingkat keabuan (grayscale) sesuai dengan jumlah bit biner yang digunakan oleh mesin. Dengan kata lain, kuantisasi pada citra menyatakan jumlah warna yang ada pada citra (Putra, 2010).

\subsubsection{RGB}

Suatu citra dalam format RGB terdiri dari tiga bidang citra yang saling lepas, masing-masing terdiri dari warna dasar: merah, hijau dan biru. Suatu warna dispesifikasikan sebagai campuran sejumlah komponen warna dasar. Gambar 1 menunjukkan bentuk geometri dari model warna RGB untuk menspesifikasikan warna menggunakan sistem koordinat cartesian. Spektrum grayscale (tingkat keabuan) adalah warna yang dibentuk dari gabungan tiga warna dasar dengan jumlah yang sama, berada pada garis yang menghubungkan titik hitam dan putih (Kadir \& Susanto, 2013).

Citra dalam format RGB mengandung data dalam bentuk matriks berukuran $r \times \mathrm{g} \times \mathrm{b}$ yang merepresentasikan warna merah, hijau, dan biru untuk setiap pikselnya. Setiap warna dasar diberikan rentang nilai. Pada layar komputer, nilai rentang paling kecil 0 dan paling besar 255. Pemilihan skala 256 ini didasarkan pada cara mengungkap 8 digit bilangan biner yang digunakan pada komputer, sehingga total warna yang dapat diperoleh adalah lebih dari 16 
juta warna. Warna dari tiap piksel ditentukan oleh kombinasi dari intensitas merah, hijau, dan biru (Putra, 2010) seperti pada Gambar 1.

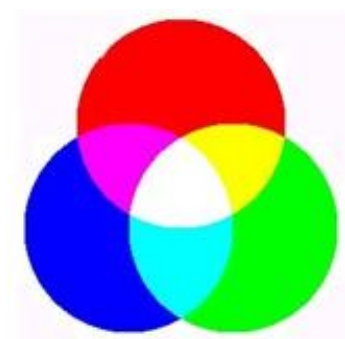

Gambar 1. Citra RGB (Putra, 2010)

\subsubsection{Grayscale}

Citra dalam format grayscale terdiri dari satu bidang citra, dimana nilai pada setiap pikselnya merupakan rata-rata dari warna dasar (merah, hijau, dan biru). Nilai-nilai piksel pada citra dalam format grayscale menunjukkan intensitas warna, dimana citra jenis ini terdiri dari warna abu-abu. Intensitas tertinggi pada citra ini akan menunjukkan warna putih, dan intensitas terlemah akan menunjukkan warna hitam. Citra dalam format grayscale berbeda dengan citra dalam format biner yang hanya terdiri dari warna hitam dan putih. Pada citra dalam format grayscale, sangat banyak variasi warna antara hitam dan putih.

Rentang nilai pada citra dalam format grayscale ini sama dengan rentang nilai pada vitra dalam format RGB, dimana nilai 0 menunjukkan intensitas terendah (warna hitam) dan nilai 255 menunjukkan intensitas tertinggi (warna putih). Untuk mengubah citra dalam format RGB yang memiliki tiga bidang citra (bidang warna merah, hijau, dan biru) menjadi citra dalam format grayscale, maka perlu dilakukan proses konversi nilai piksel citra dengan mencari rata-rata nilai piksel dari bidang warna R (Red), G (Green) dan B (B/ue) menjadi nilai G (Grayscale), sehingga dapat dituliskan dalam bentuk persamaan sebagai berikut:

$$
G=\frac{R+G+B}{3}
$$

\subsection{Haugh Unit (HU)}

\section{$1.3 \quad K$-Nearest Neighbor (K-NN)}

K-NN ( $K$-Nearest Neighbor) adalah sebuah metode untuk melakukan klasifikasi terhadap objek berdasarkan ciri-ciri data pembelajaran (data latih) yang paling mendekati objek tersebut. Ciri ini direpresentasikan dengan ukuran jarak, sehingga dapat diolah ke dalam hitungan matematis. Persamaan jarak Euclidean digunakan untuk mengukur kedekatan jarak (ciri) antara dua obyek, data latih dan data uji. (Widhiasih et al, 2013)

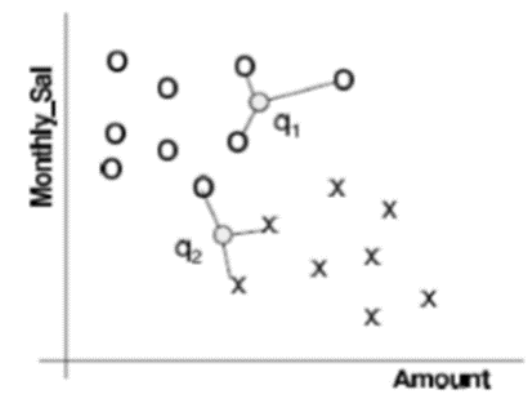

Gambar 2. Nilai K=3 Klasifikasi K-Nearest Neighbor (Padraid \& Delany, 2007) 
Gambar 2 menunjukkan klasifikasi K-NN dengan nilai K=3. Node q1 akan mendapatkan tiga tetangga terdekatnya, dimana semua tetangga terdekatnya adalah di kelas $\mathrm{O}$, sehingga node q1 diklasifikasikan sebagai kelas $\mathrm{O}$. Pada node q2, q2 mempunyai 2 tetangga dari kelas $\mathrm{X}$ dan satu tetangga dari kelas O. Algoritma K-NN:

1. Tentukan nilai $\mathrm{K}$.

2. Hitung jarak antara data baru ke setiap label data.

3. Tentukan $\mathrm{k}$ labeled data yang mempunyai jarak yang paling minimal.

4. Klasifikasikan data baru ke dalam label data yang mayoritas K-NN dipilih berdasarkan metrik jarak.

\subsubsection{Euclidean Distance}

Euclidean distance adalah jarak biasa antara dua titik atau koordinat yang diturunkan dari rumus phytaghoras. Euclidean distance antara titik dan panjang garis yang menghubungkan keduanya adalah $a b$, dimana $a b$ adalah sisi miring dari garis yang dibentuk pada sumbu $x$ dan sumbu y antara koordinat a dan b.

Sebagai contoh, untuk menghitung jarak antara dua titik Xs dan Xt dengan metode Euclidean distance, digunakan rumus (Basuki, 2016):

$$
d_{s, t}=\sqrt{\sum_{j=1}^{n}\left(s_{j}-t_{j}\right)^{2}}
$$

Keterangan:

$\mathrm{s}, \mathrm{t} \quad:$ Koordinat titik objek

$\mathrm{n} \quad$ : Jumlah objek

\subsubsection{Cityblock Distance}

Cityblock distance adalah jarak antara dua titik atau koordinat yang mirip dengan Euclidean distance. Namun sedikit berbeda dengan Euclidean distance yang mengukur panjang garis yang menghubungkan kedua titik tersebut, cityblock distance antara titik a dan b adalah nilai mutlak dari jarak antara a dan $b$ dari sumbu $x$ dan sumbu $y$.

Untuk menghitung jarak antara dua titik Xs dan Xt dengan metode cityblock distance, digunakan rumus: (Basuki, 2016)

$$
d_{s, t}=\sum_{i=1}^{n}\left|s_{j}-t_{j}\right|
$$

Keterangan:

$\mathrm{s}, \mathrm{t} \quad$ : Koordinat titik objek

n : Jumlah objek

\subsubsection{Cosine Distance}

Cosine similarity (cosine) adalah ukuran kesamaan diantara dua vektor dari sebuah inner product space yang mengukur kosinus dari sudut diantara dua vektor tersebut. Berbeda dengan dua distance measure sebelumnya yang selalu bernilai positif, cosine similarity distance memiliki rentang nilai dari -1 hingga 1 . Kosinus antara dua vektor dapat dengan mudah diturunkan dari rumus perkalian dot Euclidean. Jika vektor a dan b maka nilai kosinus dapat diperoleh dengan melakukan perkalian titik diantara keduanya. (Basuki, 2016) 
Dalam cosine distance, titik-titik dianggap sebagai vektor, dan dilakukan pengukuran terhadap sudut antara dua vektor tersebut. Untuk memperoleh jarak dua vektor xs dan xt, digunakan rumus sebagai berikut: (Basuki, 2016)

$$
d_{s, t}=1-\cos \theta
$$

dimana,

$$
\cos \theta=\frac{X s X t}{|X s||X t|}
$$

Keterangan:

$\mathrm{s}, \mathrm{t} \quad$ : Koordinat titik objek

\subsubsection{Correlation Distance}

Dalam correlation distance, titik-titik dianggap sebagai barisan nilai, jarak antar nilai xs dan xt, memakai rumus sebagai berikut: (Salsabila et al, 2016)

$$
d_{s, t}=1-\frac{\left(x_{s}-\overline{x_{s}}\right)\left(x_{t}-\overline{x_{t}}\right)}{\sqrt{\left(x_{s}-\overline{x_{s}}\right)\left(x_{t}-\overline{x_{t}}\right)}, \sqrt{\left(x_{t}-\overline{x_{t}}\right)\left(x_{t}-\overline{x_{t}}\right)}}
$$

dimana,

$$
x_{s}=\frac{1}{n}+\sum_{j} x_{s j} \text { dan } \overline{x_{t}}=\frac{1}{n}+\sum_{j} x_{t j}
$$

Keterangan:

$\mathrm{s}, \mathrm{t} \quad$ : Koordinat titik objek

n : Jumlah objek

\section{$1.4 \quad$ Kualitas Telur}

Hal yang akan dibahas pada penelitian ini adalah deteksi kualitas telur ayam negeri yang akan digunakan dalam pendeteksian kualitas telur di peternakan, pasar swalayan untuk mengurangi adanya human error. Penentuan kualitas telur berdasarkan Haugh Unit menurut standar United State Departement of Agriculture (USDA) adalah sebagai berikut: (Tim Praktikum Produksi Ternak Unggas, 2013)

1. Grade AA memiliki tinggi HU putih telur $>72$.

2. Grade A memiliki tinggi HU putih telur 60-71.

3. Grade B memiliki tinggi HU putih telur 31-59.

4. Grade $\mathrm{C}$ memiliki tinggi $\mathrm{HU}$ putih telur $<31$.

Haugh Unit merupakan satuan yang digunakan untuk mengetahui kesegaran isi telur, terutama bagian putih telur. Cara mengukurnya, telur harus dipecah lalu ketebalan putih telur diukur dengan alat micrometer. Telur yang segar biasanya memiliki putih telur tebal. Semakin tinggi nilai Haugh Unit suatu telur, maka kualitas telur semakin baik. Untuk menentukan tinggi HU, digunakan rumus: (Tim Praktikum Produksi Ternak Unggas, 2013)

$$
H U=100 \log \left(H+7,57-1,7 W^{0,37}\right)
$$

Keterangan:

HU : Nilai Haugh Unit

$\mathrm{H} \quad$ : Tinggi putih telur

W : Berat Telur 


\section{METODOLOGI PENELITIAN}

Tujuan dari penelitian ini adalah untuk memudahkan masyarakat dalam mengukur kualitas telur ayam di lapangan dengan akurat dan efisien, serta mampu mengelompokkannya berdasarkan grade telur ayam negeri yaitu grade AA (sangat baik), A (baik), B (cukup baik), dan $\mathrm{C}$ (buruk). Metodologi yang digunakan pada penelitian ini adalah sebagai berikut:

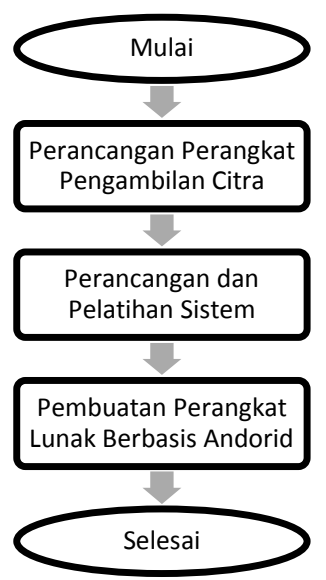

Gambar 3. Flowchart Metodologi Penelitian

Adapun penjelasan mengenai flowchart pada Gambar 3 adalah sebagai berikut:

1. Perancangan Perangkat Pengambilan Citra

Perlu dilakukan perancangan perangkat untuk pengambilan citra telur ayam negeri sehingga setiap citra yang didapatkan akan memiliki karakteristik yang sama.

2. Perancangan dan Pelatihan Sistem

Sebanyak 30 telur ayam negeri diambil citranya (10 telur grade AA, 10 telur grade A, dan 10 telur grade $\mathrm{B}$ ). grade $\mathrm{C}$ tidak dimasukkan kedalam penelitian ini, karena grade $\mathrm{C}$ merupakan kualitas telur yang sudah tidak layak konsumsi (busuk). Kemudian, setiap telur yang telah diambil citranya, dihitung nilai HU nya menggunakan HU micrometer untuk menentukan grade telur tersebut. Data ini kemudian dijadikan sebagai citra latih dan menjadi database yang akan digunakan pada perangkat lunak berbasis android.

3. Pembuatan Perangkat Lunak berbasis Android

Langkah selanjutnya adalah membuat perangkat lunak di android. Perangkat lunak ini akan mengolah citra telur ayam negeri yang akan diuji untuk dibandingkan dengan database hasil pelatihan sistem menggunakan klasifikasi K-NN. Hasil klasifikasi citra telur ayam yang diuji, akan ditampilkan pada layar smartphone berupa grading (AA, A, atau B). Jumlah telur yang diuji sebanyak 55 buah.

\subsection{Perancangan Perangkat Pengambilan Citra}
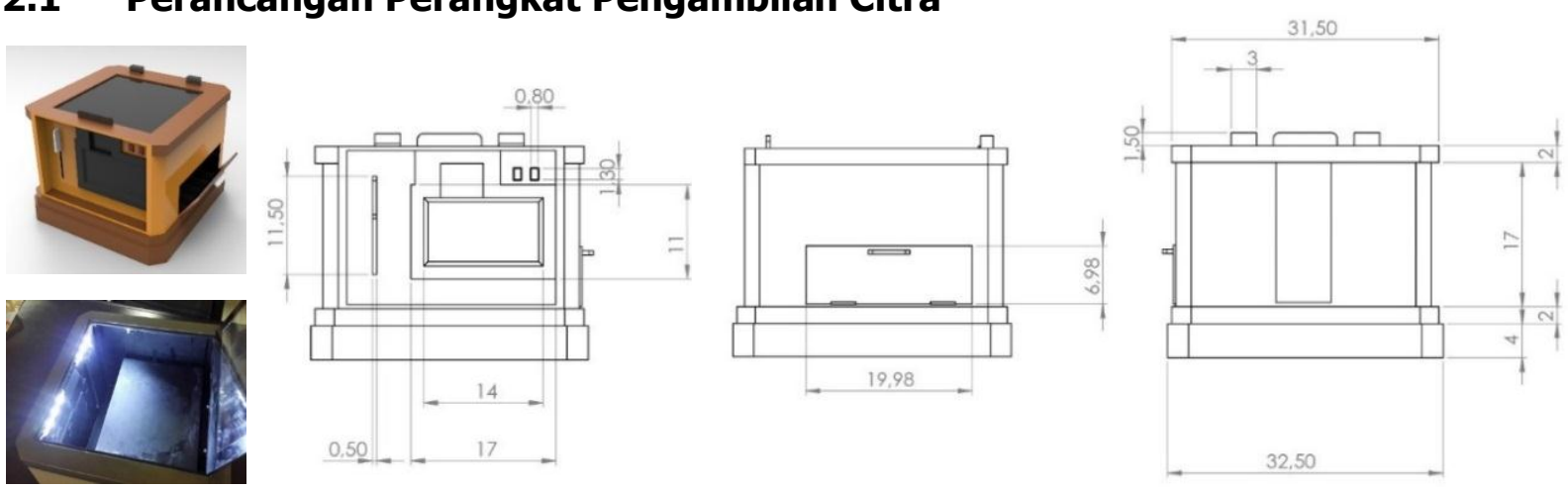

Gambar 4. Layout dan Realisasi Media Pengambilan Citra 
Gambar 4 menunjukkan desain perangkat dan realisasi perangkat yang digunakan untuk pengambilan citra telur. Telur ayam dipecahkan dan diletakkan di tengah-tengah alas yang berada di dalam perangkat, kemudian diambil citranya menggunakan kamera handphone Xiaomi Redmi 4 (dengan spesifikasi kamera 13 megapixel dengan aperture f/2.2 dan phase detection autofocus, serta platform OS Android 6.0.1 Marshmallow), dimana posisinya berada di depan alas yang jaraknya sudah fix sebesar 15,4 cm. Perangkat ini dilengkapi dengan LED sehingga pencahayaan untuk pengambilan setiap citra akan sama.

\subsection{Perancangan dan Pelatihan Sistem}

Secara umum, desain sistem dari penelitian ini direpresentasikan sebagai berikut :

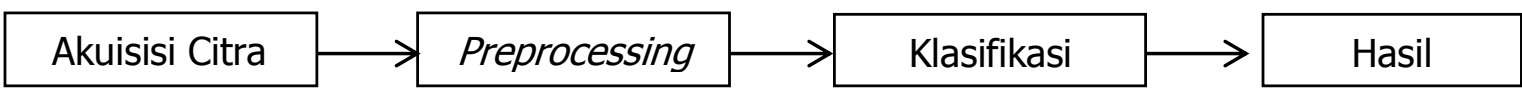

\section{Gambar 5. Blok Diagram Umum Sistem}

Adapun penjelasan mengenai blok diagram pada Gambar 5 adalah sebagai berikut:

1. Akuisisi citra adalah Pengambilan citra telur menggunakan kamera handphone Xiaomi Redmi 4 untuk mendapatkan data gambar.

2. Preprocessing adalah proses pengolahan citra digital, yang meliputi proses operasi cropping, dan grayscale.

3. Klasifikasi adalah proses pengelompokkan objek yang membedakan dengan objek lainnya dengan sistem $K$-Nearest Neighbor.

\subsubsection{Akusisi Citra}

Akuisisi citra adalah tahap untuk mendapatkan citra digital. Citra yang didapat terbagi atas citra latih dan citra uji. Proses pengambilan citra telur ayam negeri adalah dengan memecahkan telur ayam negeri terlebih dahulu diatas permukaan akrilik berwarna hitam dove. Kemudian pengambilan citra dambil dari sisi samping telur menggunakan kamera handphone. Jumlah data yang diuji sebanyak 55 citra. Pada proses ini akan dimasukkan ke dalam tahap preprocessing.

\subsubsection{Preprocessing}

Gambar 6 menunjukkan langkah-langkah proses preprocessing.

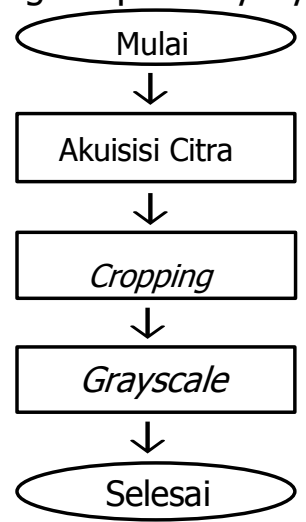

Gambar 6. Blok Diagram Tahap Preprocessing

\section{1) Akuisisi Citra}

Akuisisi citra adalah tahap untuk mendapatkan citra digital. Citra yang didapat terbagi atas citra latih dan citra uji. Pada tahap ini, proses akuisisi citra dilakukan dengan mengambil citra telur ayam negeri menggunakan kamera handphone Xiaomi Redmi 4.

2) Cropping 
Dalam tahap ini, ukuran citra di-crop menyesuaikan ukuran telur, agar lebih mudah untuk dilakukan proses klasifikasi. Ukuran data uji yang digunakan berubah menjadi $2981 \mathrm{x}$ 1018 piksel.

3) Grayscale

Pada proses ini dilakukan transformasi warna citra dari RGB menjadi grayscale dengan tujuan untuk mereduksi citra tiga dimensi menjadi satu dimensi dengan nilai intensitas yang sama, sehingga lebih mudah di proses dan bisa dijadikan citra masukan pada klasifikasi.

\subsubsection{Klasifikasi}

Gambar 7 menunjukkan flowchart klasifikasi dengan metode K-NN :

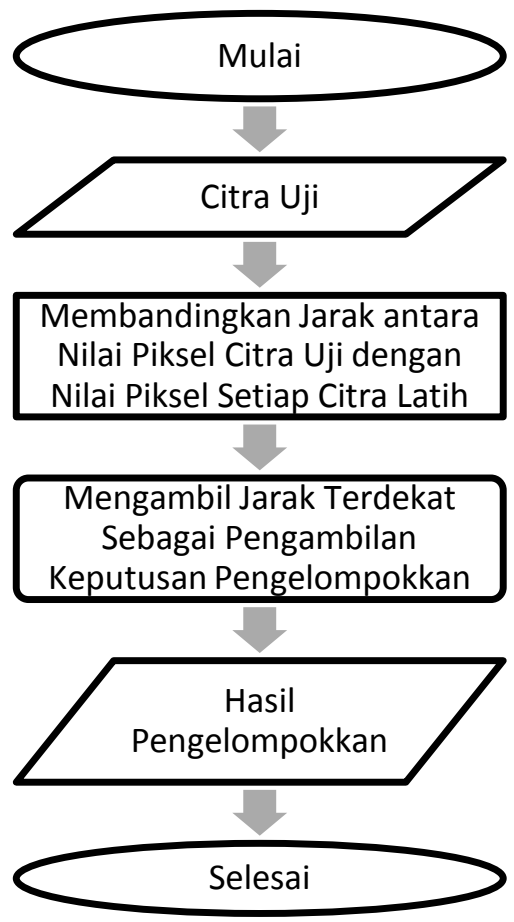

\section{Gambar 7. Flowchart Klasifikasi dengan Metode K-NN}

Adapun penjelasan langkah-langkah dari flowchart pada Gambar 7 adalah sebagai berikut:

1. Membandingkan Jarak antara Nilai Piksel Citra Uji dengan Nilai Piksel Setiap Citra Latih Nilai piksel citra uji akan dibandingkan dengan nilai piksel semua citra latih, dimana akan dicari jarak antara nilai piksel citra uji dengan nilai piksel tiap citra latih. Jarak yang dihitung berdasarkan nilai intensitas keabuan setiap piksel.

2. Mengambil Jarak Terdekat Sebagai Pengambilan Keputusan Pengelompokkan

3. Setelah mendapatkan semua jarak antara nilai piksel citra uji dengan nilai piksel semua citra latih, pengelompokkan citra uji akan dikelompokkan berdasarkan jarak terdekat antara nilai piksel citra uji dengan nilai piksel citra latih.

Pada tahap ini, masukan yang digunakan kedalam proses klasifikasi K-NN adalah hasil dari tahap preprocessing. Hal yang dilakukan klasifikasi K-NN terlebih dahulu adalah penentuan nilai K. Penentuan nilai K adalah jumlah tetangga dalam klasifikasi dengan pendekatan K-NN.

Algoritma K-NN berkerja sesuai dengan jarak terpendek dari citra uji ke citra latih. Semakin besar nilai $\mathrm{K}$ maka jumlah pembanding akan semakin besar, begitu pula sebaliknya. Analisis yang dilakukan pada penelitian ini adalah pengaruh nilai $\mathrm{K}$ yang digunakan terhadap akurasi 
sistem yang terbaik dalam mengenali ciri citra telur ayam negeri. Karena banyaknya jumlah citra latih tiap grade adalah 10, maka nilai K yang diuji adalah dari 1 sampai 9.

Tabel 1 menunjukkan ilustrasi klasifikasi dengan metode K-NN:

Tabel 1. Ilustrasi Klasifikasi Metode K-NN

\begin{tabular}{|c|c|c|c|c|c|c|c|}
\hline \multirow{2}{*}{$\begin{array}{c}\text { Citra latih } \\
\text { (Grade) }\end{array}$} & \multirow{2}{*}{$\begin{array}{c}\text { Jarak } \\
\text { dengan } \\
\text { citra uji }\end{array}$} & \multicolumn{3}{|c|}{ Penentuan jarak terdekat } & \multicolumn{3}{|c|}{ Pengambilan keputusan } \\
\hline & & $\mathrm{K}=1$ & $K=3$ & $K=5$ & $K=1$ & $K=3$ & $K=5$ \\
\hline $\mathrm{C01}(\mathrm{AA})$ & 0,2 & & & & \multirow{9}{*}{$\begin{array}{l}A A=0 \\
A=0 \\
B=1 \\
\text { Masuk } \\
\text { grade } B\end{array}$} & \multirow{9}{*}{$\begin{array}{l}\mathrm{AA}=1 \\
\mathrm{~A}=1 \\
\mathrm{~B}=1 \\
\mathrm{~B} \text { jarak } \\
\text { terdekat, } \\
\text { sehingga } \\
\text { masuk } \\
\text { grade } \mathrm{B}\end{array}$} & \multirow{9}{*}{$\begin{array}{l}\mathrm{AA}=2 \\
\mathrm{~A}=1 \\
\mathrm{~B}=2 \\
\\
\mathrm{~B} \text { jarak } \\
\text { terdekat, } \\
\text { sehingga } \\
\text { masuk } \\
\text { grade } \mathrm{B}\end{array}$} \\
\hline $\mathrm{CO2}(\mathrm{AA})$ & 0,3 & & & & & & \\
\hline $\mathrm{CO3}(\mathrm{AA})$ & 0,6 & & & & & & \\
\hline $\mathrm{CO4}(\mathrm{A})$ & 0,5 & & & & & & \\
\hline $\operatorname{C05}(A)$ & 0,1 & & & & & & \\
\hline $\mathrm{CO6}(\mathrm{A})$ & 0,35 & & & & & & \\
\hline $\mathrm{C} 07(\mathrm{~B})$ & 0,25 & & & & & & \\
\hline $\mathrm{C} 08(\mathrm{~B})$ & 0,4 & & & & & & \\
\hline $\mathrm{C09}(\mathrm{B})$ & 0,01 & & & & & & \\
\hline
\end{tabular}

Pada Tabel 1, diilustrasikan bahwa sebuah citra uji dibandingkan dengan 9 citra latih, kemudian dihitung jarak antara nilai piksel citra uji dengan nilai piksel masing-masing citra latih. Ketika menggunakan parameter $\mathrm{K}=1$, maka jarak terdekat yang dipilih adalah 1 buah, yaitu dengan citra latih C09 yang masuk dalam grade B sehingga citra uji diklasifikasikan kedalam grade $\mathrm{B}$. Ketika menggunakan parameter $\mathrm{K}=3$, maka jarak terdekat yang dipilih adalah 3 buah, yaitu dengan citra latih C01 (grade AA), C05 (grade A), C09 (grade B). Karena peluang jumlah jarak terdekat dengan tiap grade sama yaitu 1, maka pengambilan keputusan dilihat dari nilai jarak yang paling kecil, sehingga citra uji diklasifikasikan kedalam grade $\mathrm{B}$.

\subsection{Pembuatan Perangkat Lunak berbasis Android}

Gambar 8 menunjukkan flowchart yang digunakan pada pembuatan perangkat lunak berbasis android:

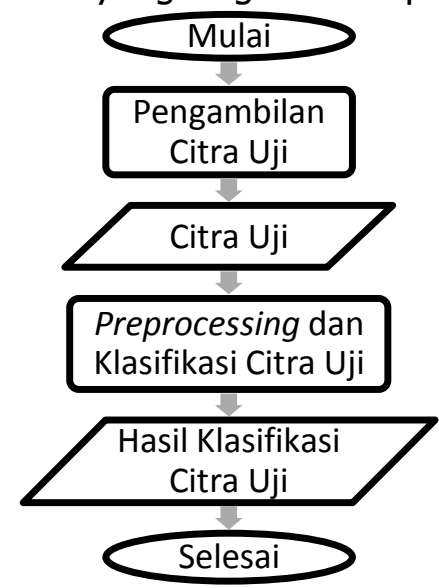

\section{Gambar 8. Blok Diagram Tahap Preprocessing}

\section{Pengambilan Citra Uji}

Telur yang akan diuji, dipecahkan terlebih dahulu dan diletakkan ditengah-tengah penampang didalam perangkat pengambilan citra, kemudian difoto menggunakan kamera smartphone yang sudah terintegrasi pada perangkat pengambilan citra. 
2. Preprocessing dan Klasifikasi Citra Uji

Selanjutnya, citra akan di proses melewati tahap preprocessing yaitu cropping dan grayscale, kemudian akan diproses lebih lanjut kedalam tahap klasifikasi menggunkana metode KNN, dimana akan dilakukan pengelompokkan kedalam kategori $A A, A$, atau $B$, dengan membandingkan jarak antara nilai pixe/ hasil preprocessing citra uji dengan database nilai pixel hasil pelatihan. Hasil pengelompokkan akan ditampilkan dilayar smartphone yang sudah terintegrasi pada perangkat pengambilan citra.

\section{HASIL DAN DISKUSI}

Pada proses pengujian ini, digunakan beberapa parameter uji, yaitu parameter layer $1=$ Red, layer 2= Green, layer 3= Blue, layer 4= Grayscale, dan metode K-NN dengan jenis distance yang digunakan yaitu Euclidean, cityblock, cosine, dan correlation. Pengujian ini dilakukan menggunakan software Matlab, karena pada aplikasi android, tidak ada tools untuk membantu mengukur beberapa parameter seperti waktu komputasi, beberapa fungsi untuk memudahkan proses pengujian. Metode penghitungan jarak yang digunakan dalam perangkat lunak berbasis android hanya cosine distance. Metode penghitungan jarak di K-NN pada library OpenCV adalah cosine distance, dan tidak bisa diubah dengan jenis distance lainnya, sehingga jarak yang digunakan hanya bisa jenis cosine distance (Puttemans, 2015). Oleh karena itu, pengujian yang dapat dilakukan pada aplikasi android adalah mengukur parameter akurasi dengan cara menguji tiap citra dan membandingkan hasil klasifikasi di android dengan hasil klasifikasi di Matlab dan hasil perhitungan menggunakan Micrometer Haugh Unit. Data yang digunakan untuk data latih adalah sebanyak 30 buah citra dan data yang diuji adalah sebanyak 55 buah citra.

Pada Gambar 9 disajikan tampilan aplikasi android yang akan digunakan untuk mengklasifikasi grade pada telur ayam negeri. Tombol import image digunakan untuk mengambil citra yang akan diuji. Pengambilan citra bisa langsung diambil dari kamera atau mengambil dari galeri. Setelah pengambilan citra, tombol process digunakan untuk memproses citra yang akan di klasifikasi grade pada citra telur.

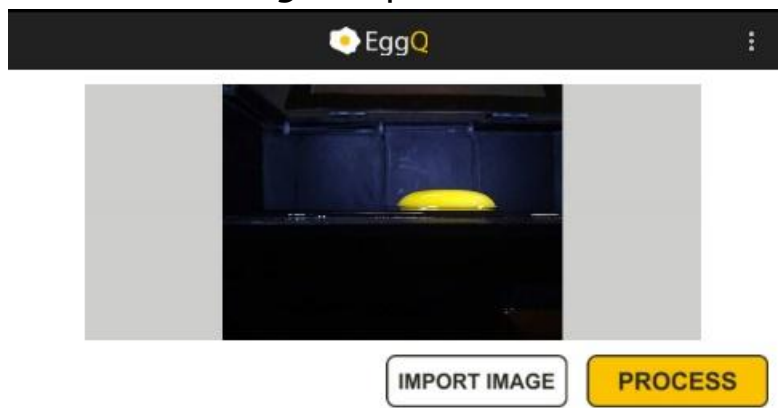

Gambar 9. Tampilan Aplikasi Setelah Pengambilan Citra

Gambar 10 menunjukkan tampilan aplikasi android setelah di klasifikasi menggunakan mtode K-NN, Hasil dari pengklasifikasian grade telur ayam negeri diatas menghasilkan grade AA yang memiliki arti sangat baik.

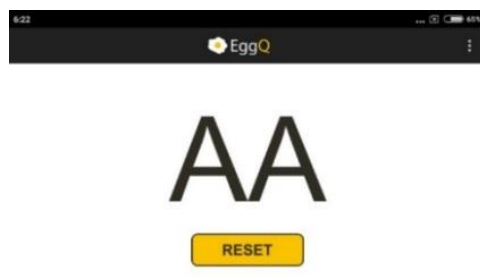

Gambar 10. Tampilan Aplikasi Setelah di Klasifikasi 
Tabel 2 dibawah ini menunjukkan data hasil pelatihan:

Tabel 2. Data Pelatihan

\begin{tabular}{c|c|c|c|c|}
\hline No & Berat (gr) & Tinggi Putih & HU & Grade \\
\hline 1 & 55 & 5,5 & 74,68 & AA \\
\hline 2 & 65,5 & 5,7 & 72,28 & AA \\
\hline 3 & 59 & 5,4 & 72,3 & AA \\
\hline 4 & 58 & 5,46 & 73,18 & AA \\
\hline 5 & 57,8 & 5,7 & 75,15 & AA \\
\hline 6 & 64,8 & 5,68 & 72,37 & AA \\
\hline 7 & 58 & 5,45 & 73,1 & AA \\
\hline 8 & 55,1 & 5,68 & 76,02 & AA \\
\hline 9 & 56 & 5,78 & 76,43 & AA \\
\hline 10 & 60 & 5,55 & 73,13 & AA \\
\hline 11 & 60,9 & 5 & 68,07 & A \\
\hline 12 & 66,3 & 4,47 & 60,38 & A \\
\hline 13 & 63,6 & 4,5 & 61,99 & A \\
\hline 14 & 59 & 4,5 & 64,19 & A \\
\hline 15 & 62,35 & 4,78 & 65,38 & A \\
\hline \multicolumn{5}{|c}{} \\
\hline
\end{tabular}

\begin{tabular}{|c|c|c|c|c|} 
No & Berat (gr) & Tinggi Putih & HU & Grade \\
\hline 16 & 62,3 & 5,17 & 69 & A \\
\hline 17 & 58,75 & 4,76 & 66,81 & A \\
\hline 18 & 60,4 & 4,98 & 68,1 & A \\
\hline 19 & 57,4 & 4,4 & 63,97 & A \\
\hline 20 & 59 & 4,35 & 62,68 & A \\
\hline 21 & 57,8 & 2,5 & 38,79 & B \\
\hline 22 & 59 & 2,7 & 41,24 & B \\
\hline 23 & 58,9 & 3,72 & 55,74 & B \\
\hline 24 & 64,8 & 3,25 & 45,69 & B \\
\hline 25 & 58 & 3,1 & 48,19 & B \\
\hline 26 & 63,45 & 3,33 & 47,79 & B \\
\hline 27 & 59,6 & 3,87 & 57,12 & B \\
\hline 28 & 58,6 & 3,25 & 49,89 & B \\
\hline 29 & 60,1 & 3,85 & 56,61 & B \\
\hline 30 & 57,5 & 2,9 & 45,6 & B \\
\hline
\end{tabular}

Data nilai HU pada Tabel 2 didapatkan dengan menggunakan Persamaan 2, dan pengklasifikasian grade mengacu pada (Tim Praktikum Produksi Ternak Unggas, 2013). Untuk memenuhi persyaratan Persamaan 2, maka digunakan timbangan dan micrometer HU untuk mendapatkan nilai HU. Hasil klasifikasi grade ini akan digunakan sebagai ciri dari tiap citra latih dan akan digunakan sebagai database untuk citra uji.

Tabel 3 menunjukkan data hasil pengujian pada Matlab dan pada aplikasi android dengan parameter layer 4 , nilai $\mathrm{K}=1$, dan metode penghitungan jarak cosine.

Tabel 3. Data Hasil Pengujian

\begin{tabular}{|c|c|c|c|c|c|c|}
\hline \multirow{2}{*}{ No } & \multirow{2}{*}{ Berat (gr) } & \multirow{2}{*}{ Tinggi Putih } & \multirow{2}{*}{ HU Rumus } & \multicolumn{3}{|c|}{ Grade } \\
\cline { 5 - 7 } & & & & Micrometer HU & Android & Matlab \\
\hline 1 & 64,4 & 7,02 & 82,29 & AA & AA & AA \\
\hline 2 & 64 & 6,88 & 81,49 & AA & AA & AA \\
\hline 3 & 68 & 10,44 & 99,61 & AA & AA & AA \\
\hline 4 & 72,9 & 8,03 & 86,27 & AA & A & A \\
\hline 5 & 66,2 & 9,19 & 94,15 & AA & AA & AA \\
\hline 6 & 69 & 7,87 & 86,31 & AA & AA & AA \\
\hline 7 & 64 & 5,49 & 71,09 & A & A & A \\
\hline 8 & 54,1 & 6,59 & 82,72 & A & AA & AA \\
\hline 9 & 62,7 & 7,65 & 86,69 & AA & AA & AA \\
\hline 10 & 55,8 & 4,13 & 62,03 & A & A & A \\
\hline 11 & 71,8 & 3,64 & 46,92 & B & B & B \\
\hline 12 & 55,9 & 2,66 & 43,08 & B & B & B \\
\hline 13 & 58 & 4,6 & 65,64 & A & A & A \\
\hline 14 & 68,9 & 3,74 & 50,11 & B & AA & AA \\
\hline 15 & 73,4 & 6,23 & 73,78 & AA & AA & AA \\
\hline 16 & 67,7 & 4,12 & 55,67 & B & B & B \\
\hline 17 & 67,1 & 4,05 & 55,14 & B & B & B \\
\hline 18 & 63,2 & 2,49 & 33,78 & B & B & B \\
\hline 19 & 70,8 & 6,94 & 79,85 & AA & AA & AA \\
\hline 20 & 71,7 & 6,31 & 74,97 & AA & B & B \\
\hline 21 & 63,9 & 4,78 & 64,68 & A & A & A \\
\hline 22 & 65,4 & 3,41 & 47,66 & B & B & B \\
\hline 23 & 66,9 & 4,78 & 63,34 & A & A & A \\
\hline 24 & 65,6 & 5,7 & 72,24 & AA & B & B \\
\hline 25 & 67,2 & 3,81 & 52,06 & B & B & B \\
\hline 26 & 59,9 & 3,19 & 48,17 & B & B & B \\
\hline 27 & 70,2 & 3,33 & 43,20 & B & A & A \\
\hline 28 & 62,3 & 3,93 & 56,33 & B & B & B \\
\hline
\end{tabular}

\begin{tabular}{|c|c|c|c|c|c|c|}
\hline \multirow{2}{*}{ No } & \multirow{2}{*}{ Berat (gr) } & \multirow{2}{*}{ Tinggi Puti } & \multirow{2}{*}{ HU Rumus } & \multicolumn{3}{|c|}{ Grade } \\
\cline { 5 - 7 } & & & Micrometer HU & Android & Matlab \\
\hline 29 & 65,4 & 3,92 & 54,48 & B & B & B \\
\hline 30 & 63,4 & 2,47 & 33,19 & B & A & A \\
\hline 31 & 66,3 & 4,48 & 60,48 & A & A & A \\
\hline 32 & 67,6 & 5,25 & 67,56 & A & A & A \\
\hline 33 & 67,4 & 5,76 & 72,07 & AA & AA & AA \\
\hline 34 & 74,9 & 3,92 & 49,07 & B & B & B \\
\hline 35 & 67,3 & 6,69 & 79,18 & AA & AA & AA \\
\hline 36 & 62,1 & 4,4 & 61,68 & A & A & A \\
\hline 37 & 62,7 & 5,69 & 73,24 & AA & B & B \\
\hline 38 & 66,3 & 4,54 & 61,13 & A & A & A \\
\hline 39 & 62,3 & 4,21 & 59,53 & B & B & B \\
\hline 40 & 72,2 & 4,66 & 59,64 & B & B & B \\
\hline 41 & 61,4 & 4,44 & 62,43 & A & A & A \\
\hline 42 & 62,1 & 7 & 82,85 & AA & A & A \\
\hline 43 & 61,7 & 6,19 & 77,42 & AA & AA & AA \\
\hline 44 & 58,1 & 6,01 & 77,37 & AA & AA & AA \\
\hline 45 & 61,5 & 5,13 & 68,98 & A & A & A \\
\hline 46 & 64,9 & 4,3 & 59,20 & B & B & B \\
\hline 47 & 58,9 & 5,8 & 75,51 & AA & A & A \\
\hline 48 & 67,4 & 2,95 & 38,86 & B & A & A \\
\hline 49 & 62,1 & 4,06 & 57,95 & B & B & B \\
\hline 50 & 55,25 & 3,7 & 57,62 & B & B & B \\
\hline 51 & 65,5 & 2,56 & 33,07 & B & B & B \\
\hline 52 & 68,8 & 3,2 & 42,08 & B & A & A \\
\hline 53 & 62,1 & 2,38 & 32,59 & B & B & B \\
\hline 54 & 54,45 & 4,5 & 66,36 & A & A & A \\
\hline 55 & 56,75 & 2,95 & 46,89 & B & B & B \\
\hline & & & & & & \\
\hline
\end{tabular}


Tabel 3 menunjukkan bahwa klasifikasi menggunakan metode K-NN pada aplikasi android dan Matlab menghasilkan nilai akurasi yang sama yaitu sebesar $80 \%$, dengan menggunakan hasil klasifikasi berdasarkan micrometer HU dan Persamaan 2 sebagai standar acuan dalam menentukan tingkat akurasi sistem. Kesalahan pengklasifikasian yang terjadi pada data Tabel 3 disebabkan oleh faktor jumlah citra latih, dimana hal ini dapat menyebabkan kekeliruan sistem dalam mendeteksi jarak terpendek antara nilai piksel citra uji dengan database nilai piksel citra latih. Semakin banyak jumlah citra latih, kemungkinan akurasi klasifikasi akan semakin tinggi. Data nilai HU Rumus pada Tabel 3 didapatkan dengan menggunakan Persamaan 2, dan pengklasifikasian grade mengacu pada (Tim Praktikum Produksi Ternak Unggas, 2013).

\subsection{Pengujian dan analisis pengaruh layer}

Berikut ini adalah data hasil pengujian parameter layer, dimana layer yang digunakan pada pengujian ini adalah $1=$ Red, $2=$ Green, $3=$ Blue, $4=$ Grayscale (Putra, 2010). Jenis distance yang digunakan adalah Euclidean dengan $\mathrm{K}=1$. Dari hasil pengujian terhadap 55 buah citra uji, tingkat akurasi tertinggi terdapat pada layer 4 dan $\mathrm{K}=1$ sebesar $81.81 \%$ dan waktu komputasi sebesar $0.0130 \mathrm{~s}$ dengan jumlah data yang benar sebanyak 45 buah. Akurasi yang didapatkan pada penelitian ini lebih kecil dibandingkan penelitian (Handayani, 2017) yang menghasilkan tingkat akurasi 90,19\%. Hal ini disebabkan pada penelitian (Handayani, 2017) digunakan kamera mirrorless dengan spesifikasi kamera FUJIFILM X-E1 dengan resolusi $16,3 \mathrm{MP}$, yang menghasilkan citra latih dan citra uji dengan nilai piksel yang lebih banyak. Hal ini akan mempengaruhi tingkat keakuratan sistem dalam pengklasifikasian.

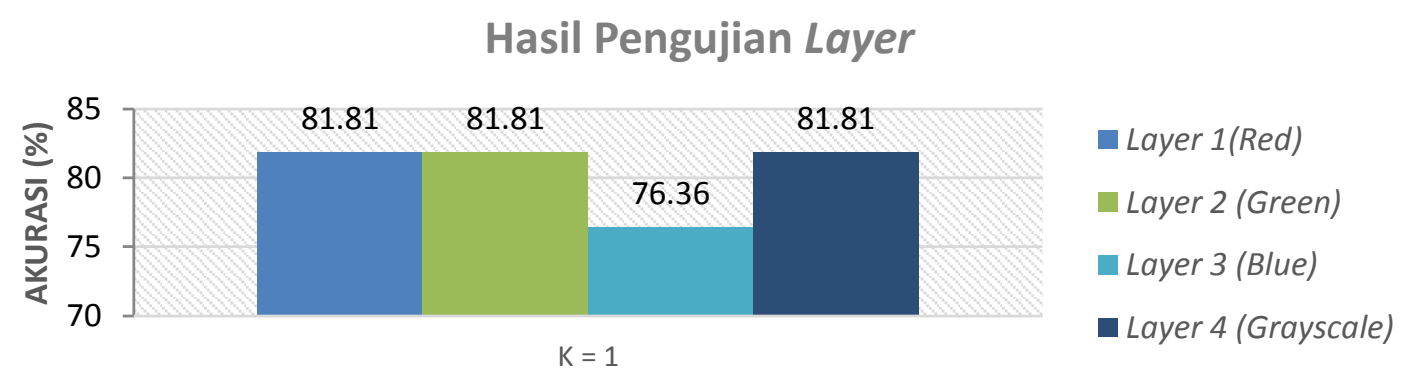

Gambar 11. Grafik Hasil Pengujian Akurasi Pada Layer

Pada Gambar 11 dapat dilihat bahwa pada layer 1, 2, dan 4 akurasi yang didapatkan memiliki nilai akurasi yang sama yaitu $81.81 \%$ sedangkan pada layer 3 , didapatkan nilai akurasi yang lebih rendah dibandingkan dengan layer yang lainnya. Hal ini disebabkan karena nilai warna kuning pada telur lebih mendekati warna merah (layer 1 ) dan warna hijau (layer 2). Pada layer 4, proses grayscaling menyebabkan nilai piksel terdistribusi merata sehingga warna kuning pada telur dapat di deteksi dengan baik.

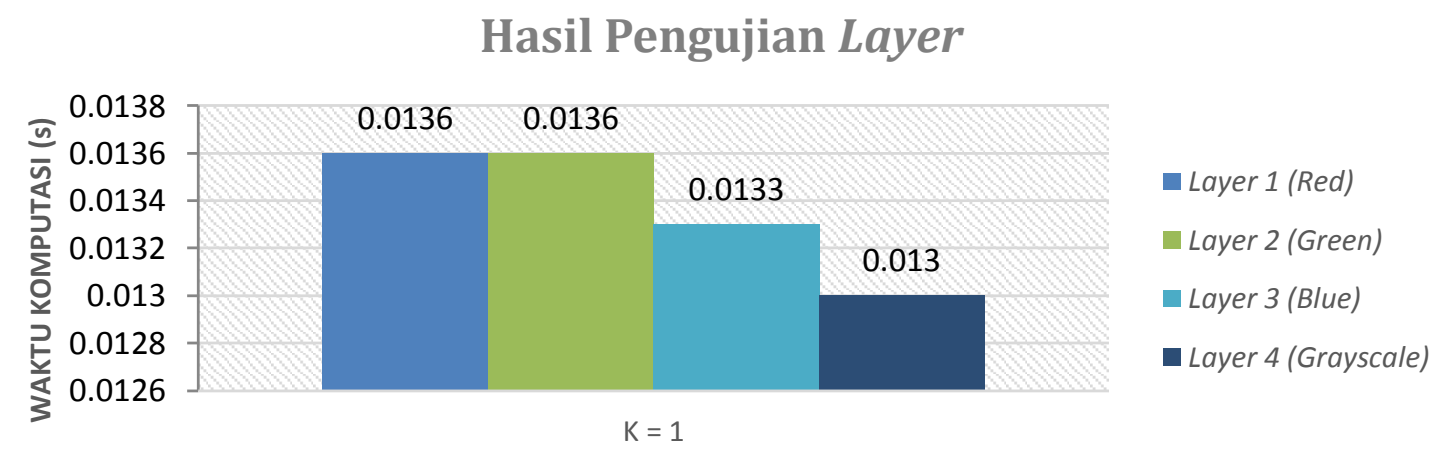

Gambar 12. Grafik Hasil Pengujian Waktu Komputasi Pada Layer 
Berdasarkan grafik pada Gambar 12, dapat dilihat bahwa waktu komputasi tercepat yang didapatkan adalah pada layer 4, karena pada proses grayscaling hanya terdapat 1 layer saja sehingga mempercepat proses pengklasifikasian pada sistem.

\subsection{Pengujian pengaruh nilai K pada klasifikasi K-NN}

Berikut ini adalah data hasil pengujian parameter $\mathrm{K}$ pada klasifikasi K-NN. Nilai K yang digunakan pada pengujian ini adalah $1,3,5$, dan 7 . Jenis distance yang digunakan adalah Euclidean, cityblock, cosine, dan correlation dengan layer 4 (Grayscale). Gambar 13 menunjukkan hasil akurasi yang paling baik didapatkan pada saat parameter nilai $\mathrm{K}=1$ dan jenis jarak Euclidean yaitu sebesar $81.81 \%$, dengan jumlah data benar sebanyak 45 dari 55 data uji. Gambar 14 menunjukkan waktu komputasi tercepat didapat saat parameter $\mathrm{K}=1$ yaitu $0.0129 \mathrm{~s}$.

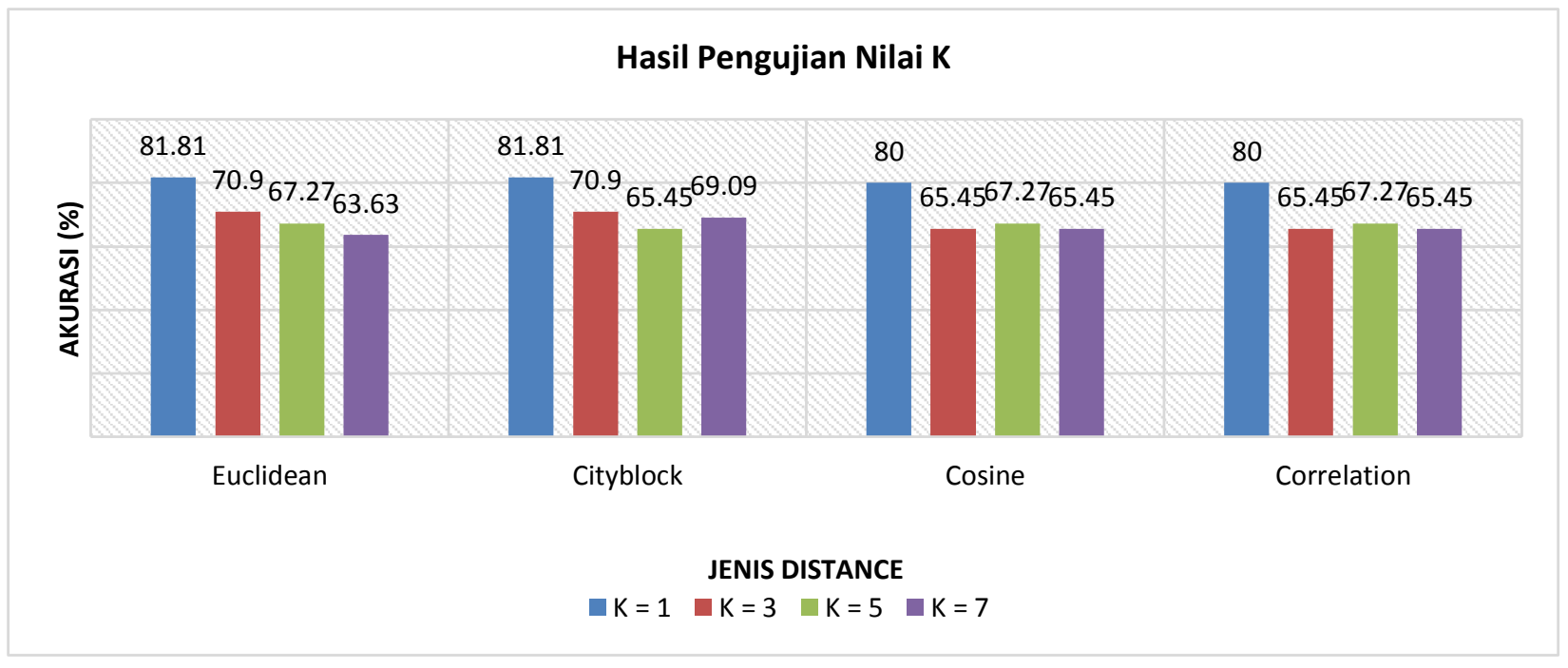

Gambar 13. Grafik Hasil Pengujian Akurasi Pada Nilai K

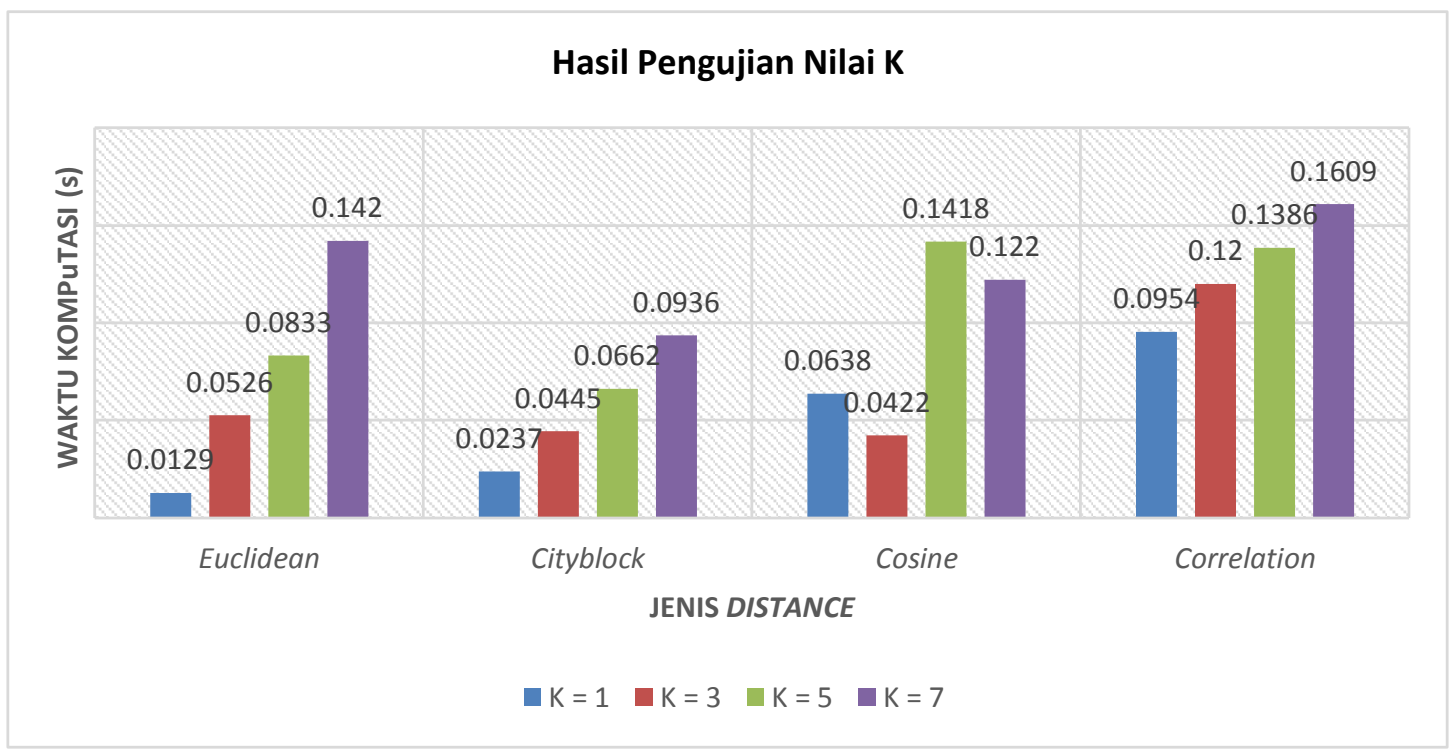

Gambar 14. Grafik Hasil Pengujian Waktu Komputasi Pada Nilai K

Pada pengujian ini, nilai akurasi terbaik didapatkan saat $\mathrm{K}=1$ pada Euclidean distance dan cityblock distance. Hal ini disebabkan karena pengambilan keputusan (pengklasifikasian) 
berdasarkan kepada satu tetangga terdekat sudah cukup mewakili karakteristik dari tiap klasifikasi yang didapat.

\section{KESIMPULAN}

Hasil dari penelitian ini menunjukkan bahwa sistem pengklasifikasian grade telur ayam negeri menggunakan klasifikasi k-nearest neighbor telah berhasil diimplementasikan pada perangkat keras berbasis android, dengan parameter layer 4 (grayscale), nilai $\mathrm{K}=1$, dan metode penghitungan jarak cosine, yang menghasilkan tingkat akurasi rata-rata terbaik sebesar $80 \%$ dengan pengukuran menggunakan micrometer $\mathrm{HU}$ sebagai pembanding. Walaupun hasil terbaik bukanlah dengan metode penghitungan jarak cosine, tetapi hasil pengujian menunjukkan perbedaan akurasi dan waktu yang tidak signifikan (selisih akurasi sebesar $1,81 \%$ dan selisih waktu sebesar 0,0509 s) dengan metode penghitungan jarak Euclidean yang menghasilkan akurasi sebesar $81,81 \%$ pada Matlab.

\section{DAFTAR RUJUKAN}

Basuki, A. F. (2016). Deteksi Kualitas dan Kesegaran Telur Berdasarkan Segmentasi Warna dengan Metode Fuzzy Color Histogram dan Wavelet dengan Klasifikasi K-NN. eProceeding of Engineering, (pp. 4404-4411).

Tim Praktikum Produksi Ternak Unggas. (2013). Penuntun Praktikum Produksi Ternak

Unggas. Sumedang: Laboratorium Ternak Unggas Fakultas Peternakan Univeristas Padjadjaran.

Putra, D. (2010). Pengolahan Citra Digital. Yogyakarta: Andi.

Handayani, N. Y. (2017). Deteksi Kualitas dan Kesegaran Telur Ayam Berbasis Deteksi Objek Transparan dengan Metode Discrete Cosine Transform (DCT) dengan Klasifikasi KNearest Neighbor (K-NN). e-Proceeding of Engineering, (pp. 1725-1732).

Kadir, A., \& Susanto, A. (2013). Teori dan Aplikasi Pengolahan Citra. Yogyakarta: Andi.

Meirinda, G. (2016). Deteksi Kualitas dan Kesegaran Telur Berdasarkan Segmentasi Warna Menggunakan Metode Fuzzy Color Histogram (FCH) dan Histogram Equalization dengan Klasifikasi K-Nearest Neighbor (K-NN) Pada Citra Digital. e-Proceeding of Engineering, (pp. 1603-1610).

Padraid, C., \& Delany, S. J. (2007). K-Nearest Neighbor Classifier. Technical Report UCD-CSI, 4, pp. 1-2.

Puttemans, S. (2015). What is the distance used by K-nearest neighbour in opencv. Dipetik pada 18 januari 2018 dari http://answers.opencv.org/question/66289/what-is-thedistance-used-by-k-nearest-neighbour-in-opencv/. 
Salsabila, R. K., Hidayat, B., \& Darana, S. (2016). Deteksi Kesegaran dan Kualitas Telur Berdasarkan Deteksi Objek Transparan dengan Metode Grey Level Co-Occurence Matrix (GLCM) dan Klasifikasi K-Nearest Neighbor (KNN). Tektrika, 1(2), 103-109.

Wardani, Y. E. (2017). Deteksi Kualitas dan Kesegaran Telur Berdasarkan Segmentasi Warna dengan Metode Fuzzy Color Histogram (FCH) dan Discrete Cosine Transform dengan Klasifikasi K-Nearest Neighbor (K-NN). e-Proceeding of Engineering, (pp. 316-324).

Widhiasih, R. N., Wahani, N. A., \& Supriyanto. (2013). Klasifikasi Buah Belimbing Berdasarkan Red-Green-Blue Menggunakan K-NN dan LDA. Jurnal Penelitian IImu Komputer, System Embedded \& Logic, 1(1), 29-35. 